\title{
PERLINDUNGAN HUKUM TERHADAP PENGETAHUAN TRADISIONAL MELALUI PENGEMBANGAN SUI GENERIS LAW
}

\section{Legal Protection to Traditional Knowledge Through the Development Sui Generis Law}

\author{
Rohaini \\ Fakultas Hukum, Universitas Lampung \\ email: rohaini.arifien81@gmail.com
}

\begin{abstract}
It's cannot deny that intellectual property right laws, in certain aspects are possible for using to protect traditional knowledge from their utilization. However, in the same time, intelectuual property rezim also become "a tool" to legitimate of biopiracy practices. Due to the massive of international pressure, mostly developing countries, and the awereness that intellectual property regimes doesn't optimal to protect traditional knowledge, it develops a discourse to develop a sui generis law outside of intellectual property right regimes. By using the normative method and qualitative approach, this research shows that in order to develop the sui generis law in Indonesia, there are several minimum elements that shall be contained in it, inter alia: the purposes of protection; scope of protection; creteria of protection; the beneficiaries of protection: the holder of traditional knowledge; the kind of rights to be granted; how does the rights acquired; how to enforce it; how does the rights lost or expired; and dispute resolution.
\end{abstract}

Keywords: protection, traditional knowledge, sui generis law

\section{abstrak}

Tidak dapat dipungkiri rezim hak kekayaan intelektual, pada beberapa aspek dapat memberikan perlindungan terhadap pengetahuan tradisional suatu negara. Namun demikian, disaat yang sama rezim hak kekayaan intelektual pulalah yang ditenggarai justru menjadi 'alat' legitimasi praktik biopiracy yang dilakukan terhadap pengetahuan tradisional yang terkait pemanfaatan sumber daya genetik. Seiring dengan kuatnya dorongan dunia internasional, mayoritas negara-negara berkembang, agar pemanfaatan pengetahuan tradisional yang merupakan kekayaan milik indigenous people sepatutnya memiliki regulasi akses dan bagi hasil yang jelas, dan kesadaran belum optimalnya peraturan-peraturan yang ada untuk melindungi pengetahuan tradisional, maka berkembang pula wacana pengembangan peraturan sui generis di luar hukum hak kekayaan intelektual. Dengan menggunakan 
metode penelitian hukum normatif dan pendekatan kualitatif, penelitian ini menyimpulkan bahwa dalam upaya pengembangan peraturan sui generis bagi pengetahuan tradisional di Indonesia, setidak-tidaknya terdapat beberapa unsur-unsur minimum yang harus terkandung dalam sebuah ketentuan sui generis, meliputi tujuan pemberian perlindungan; lingkup perlindungan; kriteria-kriteria dari objek perlindungan; keuntungan dari perlindungan: pemegang/pemilik pengetahuan tradisional; jenis hak yang diberikan; Bagaimanakah hak tersebut diperoleh?; Bagaimanakah melaksanakan dan menegakan hak-hak tersebut; Bagaimana hak tersebut hilang atau kapan hak tersebut menjadi kadaluwarsa; dan Penyelesaian sengketa.

Kata Kunci: Perlindungan, Pengetahuan Tradisional, Hukum Sui Generis

\section{A. Pendahuluan}

Secara internasional, diskusi terkait perlindungan terhadap pengetahuan tradisional sebenarnya telah dibahas lebih dari 40 tahun yang lalu. Dari diskusi-diskusi tersebut kemudian menghasilkan beberapa kesepakatan internasional yang penting terkait perlindungan bagi pengetahuan tradisional, diantaranya Konvensi Keanekaragaman Hayati (Convention on Biological Diversity) dan Protokol Nagoya tentang Akses kepada Sumber Daya Genetik dan Pembagian Keuntungan yang Adil dan Seimbang atas Pemanfaatannya (Nagoya Protocol on Access to Genetic Resources and the Fair and Equitable Sharing of Benefit Arising from Their Utilization).

Sebagai negara yang memiliki sumber daya genetik yang melimpah, multi etnis, serta budaya yang beraneka ragam, Pemerintah Indonesia begitu menyadari tingginya kepentingan Indonesia terhadap issue perlindungan pengetahuan tradisional. Kesadaran inilah yang mendorong Pemerintah Indonesia kemudian melibatkan diri secara aktif dalam diskusi-diskusi terkait upaya perlindungan bagi pengetahuan tradisional baik pada level internasional maupun regional. Selain secara aktif terlibat dalam diskusidiskusi dan pertemuan-pertemuan internasional terkait pengetahuan tradisional, Pemerintah Indonesia juga secara resmi meratifikasi regulasi internasional terkait pengakuan terhadap pengetahuan tradisional melalui Undang-Undang Republik Indonesia Nomor 5 Tahun 1994 tentang Pengesahan United Nations Convention on Biological Diversity (Lembaran Negara Republik Indonesia Tahun 1994 Nomor 41) dan Undang-undang Republik Indonesia Nomor 11 Tahun 2013 tentang Ratifikasi Pengesahan Protokol Nagoya tentang Akses pada Sumber Daya Genetik dan Pembagian Keuntungan yang Adil dan Seimbang yang Timbul dari Pemanfaatannya (Lembaran Negara Republik Indonesia Tahun 2013 Nomor 73). 
Konvensi Keanekaragaman Hayati (KKH) sendiri sebenarnya bukanlah sebuah konvensi yang secara khusus dibentuk untuk melindungi pengetahuan tradisional, namun demikian melalui KKH hak dan kedaulatan negara terhadap penguasaan dan pemanfaatan kekayaan pengetahuan tradisionalnya berdasarkan konsep akses dan bagi hasil secara adil dan merata secara internasional diakui dan digagas. Pembentukan KKH sendiri secara umum memunyai tiga tujuan utama, yaitu; (1) konservasi keanekaragaman hayati; (2) pemanfaatan komponen-komponennya secara berkelanjutan; (3) pembagian keuntungan yang dihasilkan dari pendayagunaan sumber daya genetik secara adil dan merata, termasuk melalui akses yang memadai terhadap sumber daya genetik dan dengan alih teknologi yang tepat guna, dan dengan memperhatikan semua hak atas sumber-sumber daya dan teknologi itu, maupun dengan pendanaan yang memadai. ${ }^{1}$

Lebih lanjut, dalam rangka mencapai tujuan-tujuan tersebut, dan menciptakan kepastian hukum, KKH juga memberikan peluang kepada negara-negara peserta untuk mengembangkan dua model perlindungan, yaitu model perlindungan secara positif (positive protection) dan model perlindungan secara defensif (defensive protection). Model perlindungan secara positif dapat diwujudkan melalui pengembangan hukum positif disuatu negara. Baik dengan mengoptimalkan peraturan-peraturan HKI, maupun melalui pengembangan peraturan di luar rezim HKI atau lebih sering disebut sebagai sui generis law. Model perlindungan secara positif nantinya akan memberikan hak intelektual atas objek yang dimintakan perlindungan. Sebaliknya, perlindungan secara defensif tidak akan memberikan hak kekayaan intelektual. Model perlindungan secara defensif lebih bertujuan untuk mencegah dan menyetop pemberian hak kekayaan intelektual kepada pihak-pihak yang tidak berhak. Pada umumnya model perlindungan ini dikembangkan dalam bentuk inventarisasi pengetahuan tradisional di suatu negara, baik dalam bentuk database pengetahuan tradisional sebagaimana yang dilakukan oleh India, database jurnal pengetahuan tradisional seperti yang dikembangkan oleh Korea Selatan, ataupun sebagaimana yang dikembangkan oleh China melalui database pengobatan tradisional China. Namun demikian, tidak ada kewajiban bagi satu negara untuk mengembangkan kedua-duanya. Setiap negara dibebaskan untuk mengembangkan model perlindungan sesuai dengan kebutuhan masing-masing.

Dengan menggunakan metode penelitian hukum normatif dan pendekatan kualitatif, tulisan ini dikhususkan untuk membahas lebih jauh salah satu model perlindungan, yaitu model perlindungan secara positif

\footnotetext{
${ }^{1}$ Pasal 1 Konvensi Keanekaragaman Hayati
} 
melalui pengembangan hukum tertentu di luar rezim hak kekayaan intelektual (sui generis law).

\section{B. Pembahasan}

\section{Konsep Umum Pengetahuan Tradisional}

Sebelum kita membahas lebih jauh mengenai perlindungan terhadap pengetahuan tradisional, ada beberapa hal pokok terkait pengetahuan tradisional yang terlebih dahulu kita harus pahami. Salah satu diantaranya mengenai terminologi pengetahuan tradisional itu sendiri.

Terminologi pengetahuan tradisional yang digunakan dalam tulisan ini, sejatinya bukanlah terminologi tunggal yang digunakan dalam diskusidiskusi terkait pengetahuan tradisional. Terdapat hampir 20 istilah berbeda yang digunakan untuk pengetahuan tradisional. ${ }^{2}$ Diantaranya "pengetahuan lokal (local knowledge)", "pengetahuan asli (indigenous knowledge)", "pengetahuan tradisional (traditional knowledge)", "pengetahuan ekologi tradisional (traditional ecological knowledge)", "cerita rakyat (folklore)", "benda cagar budaya (cultural property)", dan lain-lain. Semua istilah ini pada prinsipnya sama-sama berfokus pada sebuah konsep pengetahuan yang telah lama dikenal dalam kelompok masyarakat tertentu, sedangkan perbedaannya terletak pada orientasi masyarakat yang dituju. ${ }^{3}$ World Intellectual Property Organization (WIPO) dan Secretariat of Convention on Biological Diversity sendiri dalam dokumen-dokumen yang mereka terbitkan cenderung lebih menggunakan istilah "pengetahuan tradisional (traditional knowledge)".

\section{a. Pengertian Pengetahuan Tradisional}

Meskipun diskusi terkait perlindungan terhadap pengetahuan tradisional telah dilakukan lebih dari empat puluh tahun silam, namun demikian secara internasional hingga saat ini belum ada keseragaman definisi pengetahuan tradisional yang disepakati. Terdapat berbagai macam definisi pengetahuan tradisional dalam literatur, baik yang diusulkan oleh organisiasi internasional maupun oleh para sarjana dan ahli. Beberapa diantaranya:

Secretariat of Convention on Biological Diversity (CBD) mendefinisikan pengetahuan tradisional sebagai berikut:

"Traditional knowledge refers to the knowledge, innovations and practices of indigenous and local communities around the world.

\footnotetext{
${ }^{2}$ Dokumen WIPO/GRTKF/IC/3/9 (May 20 $\left.{ }^{\text {th }}, 2002\right)$, hlm. 18

${ }^{3}$ Gazalba Saleh, Upaya Perlindungan Hukum Bagi Pengetahuan Tradisional di Negaranegara Berkembang Khususnya Indonesia, dalam Jurnal Supremasi Hukum, Volume III No. 1 (Jakarta: FH Univ. Sahid, 2010), hlm. 2.
} 
Developed from experience gained over the centuries and adapted to the local culture and environment, traditional knowledge is transmitted orally from generation to generation. It tends to be collectively owned and takes the form of stories, songs, folklore, proverbs, cultural values, beliefs, rituals, community laws, local language, and agricultural practices, including the development of plant species and animal breeds. Sometimes it is referred to as an oral traditional for it is practiced, sung, danced, painted, carved, chanted and performed down through millennia. Traditional knowledge is mainly of a practical nature, particularly in such fields as agriculture, fisheries, health, horticulture, forestry and environmental management in general." 4

Sementara The Director General of United Nations Educational, Scientific and Cultural Organization menjelaskan pengetahuan tradisional secara umum sebagai:

"The indigenous people of the world possess an immense knowledge of their environments, based on centuries of living close to nature. Living in and from the richness and variety of complex ecosystems, they have an understanding of the properties of plants and animals, the functioning of ecosystems and the techniques for using and managing them that is particular and often detailed. In rural communities in developing countries, locally occurring species are relied on for many - sometimes all - foods, medicines, fuel, building materials and other products. Equally, people's knowledge and perceptions of the environment, and their relationships with it, are often important elements of cultural identity".

Di samping definisi yang diformulasikan organisasi-organisasi internasional, kita dapat juga merujuk pada definisi yang diformulasikan oleh para sarjana dan ahli. Diantaranya sebagaimana yang disebutkan oleh Peter Jaszi. Dengan merujuk pada definisi-definisi pengetahuan tradisional yang telah ada sebelumnya, Peter Jaszi secara umum mendefinisikan pengetahuan tradisional sebagai pengetahuan yang dihasilkan dari aktivitas intelektual yang dikembangkan berdasarkan pengalaman dan pengamatan yang lalu, yang memiliki sifat dinamis dan karakter yang selalu berubah

\footnotetext{
${ }^{4}$ Secretariat of CBD, Traditional Knowledge and the Convention on Biological Diversity $(C B D)$, http://www.cbd.int/traditional/intro.shtml (diakses tanggal 8 Oktober 2014).

${ }^{5}$ Native Science Organization, What is Traditional Knowledge: Traditional Knowledge Systems in the Arctic, http://www.nativescience.org/html/traditional_knowledge.html (diakses tanggal 21 Oktober 2014)
} 
berdasarkan kebutuhan dan perubahan masyarakat. ${ }^{6}$ Sejalan dengan Peter Jaszi, J. Janewa mendefinisikan pengetahuan tradisional sebagai hasil dari aktivitas intelektual yang diturunkan antar generasi, dan berhubungan dengan kelompok masyarakat tertentu. ${ }^{7}$ Pengetahuan ini menekankan pada akumulasi dan transmisi pengetahuan antar generasi. ${ }^{8}$

Berdasarkan beberapa definisi di atas, sebagai sebuah pengetahuan yang diwariskan, secara umum harus diingat bahwa pengetahuan tradisional tidak terbatas pada satu bidang tertentu saja. Pengetahuan ini terkait dengan semua aspek kehidupan, dan lingkungan. ${ }^{9}$ Dikonteks internasional sendiri telah disepakati bahwa pengetahuan tradisional meliputi bidang pertanian, ilmu pengetahuan, teknik, ekologi, dan pengetahuan pengobatan ${ }^{10}$, juga pengetahuan yang berkaitan dengan sumber daya genetik. ${ }^{11}$

\section{b. Karakteristik Pengetahuan Tradisional}

Meskipun secara universal belum ada definisi tunggal pengetahuan tradisional yang disepakati, poin penting yang dapat kita sepakati adalah bahwa dari semua definisi yang ada saat ini, baik diusulkan oleh organisasi pemerintah internasional, NGO, ataupun oleh para ahli, seluruh definisi tersebut diciptakan untuk saling melengkapi satu dengan yang lainnya.

Selanjutnya, berdasarkan semua definisi yang ada, secara umum kemudian disimpulkan beberapa karakter umum pengetahuan tradisional, diantaranya: bahwa pengetahuan tradisional merupakan pengetahuan yang meliputi tradisi yang didasarkan pada inovasi, kreasi, dan praktik-praktik yang merupakan bentuk awal, dan digunakan oleh komunitas adat; Pengetahuan tradisional diturunkan secara lisan dari generasi ke generasi. Kondisi ini pada akhirnya menciptakan pengetahuan tradisional bersifat nonstatis. Sebagai sebuah pengetahuan yang non-statis, pengetahuan ini selalu mengalami modifikasi yang kemudian diadopsi dengan perubahan sesuai

\footnotetext{
${ }^{6}$ Peter Jaszi, et.al., "A Step Forward for Protection in Indonesia", dalam Dewi Avilia, Traditional Knowledge Database: A Defensive Measure Against Traditional Knowledge Cross Border Misappropriation, Master Thesis (Netherland: Tilburg University), hlm. 7, http://arno.uvt.nl/show.cgi?fid=115001 (diakses tanggal 10 Juni 2013).

${ }^{7}$ J. Janewa OseiTutu, A Sui Generis Regime for Traditional Knowledge: The Cultural Divide in Intellectual Property Law, dalam Marquette Intellectual Property L. Rev., Vol. 15 (2011), hlm. 164.

${ }^{8}$ Joseph M Wekundah, Why Protect Traditional Knowledge?, dalam African Technology Policy Studies Network, Special Paper Series No. 44 (2012), hlm. 8.

${ }^{9}$ Rabodo Andriantsiferana, Traditional Knowledge: What is it and How (if at All) is it to be Protected? Traditional Knowledge Protection in the African Region, Conference on Biodiversity, Biotechnology and the Protection of Traditional Knowledge (Saint Louis: USA, April $\left.4^{\text {th }}-6^{\text {th }}, 2003\right)$, hlm. 3 .

${ }^{10}$ Dokumen WIPO/GRTKF/IC/3/9 (May 20 $\left.{ }^{\text {th }}, 2002\right)$, loc. cit.

${ }^{11}$ Peter Jaszi, loc. cit.
} 
kebutuhan pemakainya; Pengetahuan tradisional juga kebanyakan dimiliki oleh masyarakat (komunal) bukan oleh individu; Pemanfaatannya pun lebih banyak untuk menyokong kehidupan dari pemilik atau pencipta pengetahuan tradisional tersebut, bukan untuk orientasi keuntungan (non-profit orientation $)^{12}$; Lebih jauh, subjek dari pengetahuan tradisional sangatlah luas, meliputi hampir seluruh bidang kehidupan manusia seperti: seni, kesehatan, makanan, pertanian, perumahan, dan lain-lain.

Dengan mempertimbangkan karakter-karakter tersebut di atas, poin penting yang harus diingat adalah bahwa kesemuanya itu merupakan gaya hidup dan mengandung kearifan lokal satu komunitas adat yang kemudian menjelma menjadi identitas komunitas tersebut.

\section{c. Pengetahuan Tradisional: Mengapa Harus Dilindungi?}

Merujuk pada diskusi-diskusi tentang perlindungan bagi pengetahuan tradisional, ada beberapa alasan yang mendasari negara-negara berkembang dan agen-agen pembangunan menuntut keterlibatan dunia internasional dalam upaya pemeliharaan, pengembangan, dan perlindungan bagi pengetahuan tradisional, diantaranya:

Pertama: karena pengetahuan tradisional memainkan peranan penting dalam kehidupan ekonomi dan sosial suatu negara. Dengan mengakui dan meningkatkan nilai-nilai yang dikandung dalam pengetahuan tradisional akan membantu penguatan identitas dan peningkatan pemanfaatannya untuk mencapai tujuan sosial dan pembangunan. Singkatnya, pengetahuan tradisional memiliki potensi untuk menciptakan pembangunan ekonomi yang berkesinambung di banyak negara. ${ }^{13}$ Kedua; negara-negara berkembang dan negara-negara maju menerapkan kesepakatan internasional yang memengaruhi bagaimana pengetahuan tradisional yang berkaitan dengan sumber daya genetik dilindungi dan disebarluaskan. dengan demikian maka kepentingan nasional mereka pun dilindungi. ${ }^{14}$

Selain itu, dalam ranah hak kekayaan intelektual sendiri telah terjadi perkembangan doktrin terkait ruang lingkup perlindungan hak kekayaan

\footnotetext{
${ }^{12}$ Christoph Beat Grabet \& Martin A. Girsberger, Traditional Knowledge at the International Level: Current Approaches and Proposal for a Bigger Picture That Includes Cultural Diversity (2006), hlm. 247, http://www.unilu.ch/files/graber-girsberger_tkcd_endg.pdf (diakses tanggal 21 Oktober 2013).

${ }^{13}$ Di luar negara-negara berkembang, pengetahuan tradisional seringkali digunakan sebagai pintu masuk bagi pengembangan industri modern seperti industri obat-obatan, farmasi, pertanian, dan pestisida. Sementara bagi banyak negara berkembang, pengetahuan tradisional justru dijadikan sebagai salah satu stimulus yang efektif untuk meningkatkan pertumbuhan ekonomi melalui pemanfaatan secara komersil sumber daya genetiknya yang berhubungan dengan pengetahuan tradisional.

${ }^{14}$ WIPO Publication No. 920 Booklet No. 2, Hlm. 10.
} 
intelektual. Salah satu penyebab perkembangan itu adalah karena adanya pandangan bahwa hak yang menyangkut kekayaan intelektual tidak akan terlepas dari hak-hak yang dimiliki manusia yang bersifat asasi, baik secara personal maupun secara suatu kesatuan manusia yang terorganisasi. Dalam hubungan yang saling terkait inilah kemudian pengetahuan tradisional atau indigenous knowledge menjadi bagian yang mendapatkan perlindungan dalam kerangka perlindungan hak kekayaan intelektual. ${ }^{15}$

Lebih lanjut, secara umum setidaknya ada 5 alasan utama mengapa pengetahuan tradisional harus dilindungi, yaitu:

1) Keadilan (equity)

Adalah sebuah kewajaran dan keadilan apabila pemilik pengetahuan tradisional yang pengetahuannya dimanfaatkan dan dikomersialisasi mendapatkan bagi hasil atau kompensasi baik bersifat moneter maupun non-moneter;

2) Konsevasi (conservation)

Perlindungan bagi pengetahuan tradisional, berarti juga pelindungan bagi pemeliharaan lingkungan, keanekaragaman hayati, dan kegiatan pertanian yang berkelanjutan;

3) Memelihara praktik-praktik tradisional dan budaya (preservation)

Perlindungan terhadap pengetahuan tradisional dapat digunakan untuk meningkatkan nilai dan kepercayaan masyarakat baik di dalam ataupun luar komunitas atas nilai-nilai pengetahuan tradisional;

4) Mencegah penyalahgunaan oleh pihak yang tidak berhak atau menghindari bio-piracy (avoiding bio-piracy)

Perlindungan bagi pengetahuan tradisional adalah salah satu jalan untuk mengurangi praktik bio-piracy, sekaligus menjamin keadilan dan perlakuan yang seimbang antara pemilik dan pengguna pengetahuan tradisional. Menurut Moni Wekesa ${ }^{16}$ untuk mencegah terjadinya tindakan penyalahgunaan pengetahuan tradisional, setidaknya ada tiga hal penting yang harus diperhatikan:

a) Pertama: pendokumentasian pengetahuan tradisional dilakukan melalui pembangunan database traditional knowledge;

b) Kedua: kewajiban persyaratan untuk mencantumkan asal dari material yang akan dimohonkan perlindungan hukumnya melalui rezim intelectual property;

c) Ketiga: bagi pihak-pihak yang akan mencari pengakuan hukum melalui rezim HKI, harus mampu menunjukkan bukti persetujuan pemanfaatan, pembagian kepemilikan, maupun pembagian keuntungan dari pemilik pengetahuan tradisional.

\footnotetext{
${ }^{15}$ Muhammad Djumhana, R. Djubaedillah, Hak Milik Intelektual Sejarah, teori, dan Praktiknya di Indonesia, (Bandung: PT. Citra Aditya, 2014), Hlm.12.

${ }^{16} \mathrm{Ibid}, \mathrm{Hlm} .8$.
} 
5) Sebagai upaya promosi atas pemanfaatan dan pentingnya pengembangan pengetahuan tradisional (promotion of its use)

Selain upaya perlindungan dengan membatasi akses ke pengetahuan tradisional, pemerintah harus juga memunyai tujuan untuk mendukung pemanfaatan dari pengetahuan tradisional itu sendiri, dan mengembangkan usaha-usaha yang bertujuan untuk mencegah penyalahgunaan. ${ }^{17}$

Upaya untuk melindungi pengetahuan tradisional dalam realitanya tidaklah semudah membalikan telapak tangan. Salah satunya disebabkan perspektif perlindungan dari negara-negara maju cenderung berbeda dengan perspektif negara-negara berkembang. Dalam perspektif negara maju, mereka lebih berfikir bagaimana caranya untuk memperoleh akses seluasluasnya kepada pengetahuan tradisional guna menciptakan produk-produk baru, dan mendapatkan keuntungan yang besar dari komersialisasi produkproduk tersebut. Sementara perspektif negara-negara berkembang, khususnya yang memiki keanekaragaman hayati dan pengetahuan tradisional yang melimpah, mereka lebih berfikir tentang bagaimana menciptakan sebuah mekanisme pembagian keuntungan yang adil dan seimbang atas pemaanfaatan keduanya.

Namun demikian, meskipun terdapat perbedaan perspektif antara negara maju dan negara berkembang, satu hal yang disepakati adalah bahwa melindungi keanekaragaman hayati yang berkaitan dengan pengetahuan tradisional merupakan hal penting dan harus dilakukan oleh kedua belah pihak, karena kemusnahan keduanya akan berakibat pada musnahnya keanekaragaman budaya global, dan hal ini secara otomatis akan berakibat pula pada kelestarian dan keanekaragaman. Selain itu, alasan lain mengapa traditional knowledge harus dipertahankan, dikembangkan dan dilindungi adalah mengingat di luar kelompok negara-negara maju (LDCs/least developed countries), pengetahuan tradisional sering digunakan sebagai pintu masuk pada sebuah industri modern seperti farmasi, pertanian, pestisida alami, dan lain-lain. Sementara bagi negara berkembang, kesadaran bahwa dengan mengefektifkan pemanfaatan kekayaan hayati dan pengetahuan tradisional yang dimilikinya, pengetahuan tradisional dapat menjadi sebuah perangsang pertumbuhan ekonomi.

\section{d. Bagaimana Cara Melindunginya?}

${ }^{17}$ Carlos M Correa, Protection and Promotion of Traditional Medicine Implications for Public Health in Developing Countries (2002), hlm. 5, http://apps.who.int/medicine docs/pdf/s4917e/s4917e.pdf (diakses tanggal 3 Mei 2013). 
Merujuk pada Duffield, dalam rangka melindungi pengetahuan tradisional, setidaknya terdapat tiga model perlindungan yang dapat dikembangkan, yaitu: ${ }^{18}$

\begin{tabular}{|c|c|c|}
\hline $\begin{array}{c}\text { Memanfaatkan } \\
\text { Peraturan yang } \\
\text { Telah Ada } \\
\text { Sebelumnya }\end{array}$ & $\begin{array}{c}\text { Modifikasi/Aturan } \\
\text { Tambahan/Pelengkap }\end{array}$ & $\begin{array}{c}\text { Mengembangkan } \\
\text { Peraturan yang Bersifat } \\
\text { Khusus 'Sui Generis' }\end{array}$ \\
\hline Hukum adat & $\begin{array}{lr}\text { Kodifikasi } & \text { dan } \\
\text { pengakuan } & \text { secara } \\
\text { formal } & \text { ketentuan- } \\
\text { ketentuan } & \text { dalam } \\
\text { hukum adat } & \end{array}$ & --- \\
\hline $\begin{array}{l}\text { Kontrak, perjanjian } \\
\text { transfer yang } \\
\text { seimbang, dan konsep } \\
\text { hukum publik dan } \\
\text { sipil lainnya }\end{array}$ & $\begin{array}{l}\text { Kesepakatan akses dan } \\
\text { bagi hasil }\end{array}$ & $\begin{array}{l}\text { Ketentuan terhadap } \\
\text { manajemen } \\
\text { keanekaragaman hayati } \\
\text { dengan } \quad \text { kewajiban- } \\
\text { kewajiban } \\
\text { pengetahuan tradisional; } \\
\text { akses terhadap peraturan } \\
\text { perundang-undangan. }\end{array}$ \\
\hline $\begin{array}{l}\text { Hukum hak kekayaan } \\
\text { intelektual }\end{array}$ & $\begin{array}{l}\text { Sertifikat asal materi, } \\
\text { Prior Inform Consent } \\
\text { (PIC), dan lain-lain. }\end{array}$ & $\begin{array}{l}\text { Kategori baru dalam } \\
\text { hukum } \\
\text { intelektual. }\end{array}$ \\
\hline
\end{tabular}

Konsep perlindungan terhadap pengetahuan tradisional sebagaimana yang diuraikan oleh Duffield di atas, sejalan dengan model perlindungan yang dikembangkan oleh World of Intellectual Property Rights (WIPO). WIPO secara umum mengajukan dua model perlindungan, yaitu:

1) Perlindungan yang bersifat mencegah (defensive protection)

Dalam konteks pengetahuan tradisional, terminologi defensive protection merujuk pada usaha yang bertujuan untuk mencegah pemberian hak kekayaan intelektual atas pengetahuan tradisional atau sumber daya genetik yang berkaitan dengan pengetahuan tradisional oleh pihak lain tanpa

\footnotetext{
${ }^{18}$ Karin Timmermans (ed), "TRIPS, CBD and Traditional Medicine: Concept and Questions", Report of an ASEAN Workshop the TRIPS Agreement and Traditional Medicine Jakarta, 13-15 Feb 2001 (2001), Hlm. 32.
} 
sepengetahuan dan izin dari pemilik pengetahuan tradisional. ${ }^{19}$ Perlindungan secara defensif sendiri terdiri dari dua aspek: ${ }^{20}$

a) legal aspek, adalah bagaimana memastikan batasan kriteria terkait prior art bagi pengetahuan tradisional, sebagai contoh, dengan memastikan di dalam undang-undang bahwa pengungkapan pengetahuan atau informasi pengetahuan tradisional secara oral merupakan prior art; dan

b) aspek praktis, adalah bagaimana memastikan pengetahuan tradisional tersedia dan terbuka untuk diakses serta dapat dibaca oleh otoritas dan atau petugas paten.

\section{2) Perlindungan secara positif (positive protection)}

Defensive protection dapat menjadi salah satu kebijakan yang efektif untuk mencegah diberikannya hak kekayaan intelektual kepada pihak yang tidak berhak. Namun demikian, hal ini tidak secara otomatis menghentikan dilakukannya perbuatan missappropriation/biopiracy atas pengetahuan tradisional. Dibutuhkan hukum nasional untuk menyupport pelaksanaan kebijakan ini. Bagaimanapun, hukum positif adalah mekanisme utama dalam upaya untuk mencapai perlindungan dan pembagian keuntungan (benefit sharing) bagi pemilik pengetahuan tradisional. Positive protection sendiri dapat dilakukan dalam dua bentuk upaya hukum, yaitu dengan mengefektifkan penggunaan undang-undang yang terkait hak kekayaan intelektual, atau melalui pembentukan undang-undang khusus yang terkait pengetahuan tradisional (sui generis law).

\section{Pembentukan Peraturan Sui Generis}

Secara terminilogi, sui generis berasal dari bahasa latin yang berarti "bersifat khusus". Dalam ranah hukum kekayaan intelektual, istilah ini merujuk pada bentuk khusus dari perlindungan di luar bentuk perlindungan yang telah digunakan. Ini bisa juga dilihat sebagai sebuah pembentukan rezim khusus dalam rangka kebutuhan tertentu. ${ }^{21}$ Dalam konteks perlindungan terhadap pengetahuan tradisional, rezim ini bagi beberapa negara, salah satunya Indonesia, menjadi perlu mengingat meskipun rezim hak kekayaan intelektual dianggap mampu memberikan perlindungan terhadap subjek-subjek tertentu dari pengetahuan tradisional, ${ }^{22}$ namun demikian di saat saat sama, prinsip-prinsip tertentu yang terdapat dalam

\footnotetext{
${ }^{19}$ Dokumen WIPO/GRTKF/IC/5/6 (May $14^{\text {th }}, 2003$ ).

${ }^{20}$ Dokumen WIPO/GRTKF/IC/6/8 (December $15^{\text {th }}, 2003$ ).

${ }^{21}$ Moni Wekesa, What is Sui Generis System of Intelektual Property Protection?. African Tecnolgy Policy Studies Network (ATPS): Nairobi, Kenya (2006), Hlm. 3.

${ }^{22}$ Hasan, Emmanuel, et.al., Intellectual Property and Developing Countries: a review of the Literature. RAND Corporation: UK (2010), Hlm. 44-45.
} 
rezim HKI tersebut dianggap belum mampu bahkan berpotensi menghambat tercapainya kesetaraan (equity-oriented) bagi komunitas tradisional itu sendiri. ${ }^{23}$

Kesadaran bahwa perlindungan terhadap pengetahuan tradisional tidak dapat hanya mengandalkan ketentuan-ketentuan dalam rezim HKI, pada level internasional, tercatat beberapa negara anggota HKK telah mengembangkan model perlindungan sui generis, diantaranya Brazil melalui Provitional Act No.2.186-16 tertanggal 23 Agustus, 2001, India melalui the Biological Diversity Act, 2002 18, Filipina melalui the Indigenous Peoples Rights Act of 1997 (Republic Act No. 8371), dan Thailand melalui Act on Protection and Promoting of Traditional Thai Medicine Intelligence, B.E 2542.

Terkait dengan perlindungan terhadap pengetahuan tradisional di Indonesia, pemerintah sendiri sebenarnya telah berusaha melindungi pengetahuan tradisional Indonesia melalui pemanfaatan beberapa peraturan terkait HKI, seperti Hak Cipta sebagaimana tertuang dalam ketentuan Pasal 38 jo Pasal 40 Undang-undang Nomor 28 Tahun 2014 tentang Hak Cipta yang mengatur bahwa negara memegang hak cipta atas ekspresi budaya tradisional. Selain diatur dalam Undang-undang Hak Cipta, pengetahuan tradisional Indonesia juga diatur dalam Undang-undang Nomor 29 Tahun 2000 tentang Perlindungan Varietas Tanaman. Termasuk juga Hukum Paten. Selain memanfaatkan peraturan terkait hak kekayaan intelektual untuk melindungan pengetahuan tradisional di Indonesia, kebijakan terkait pengetahuan tradisional secara tersirat dapat ditemukan dalam ketentuan seperti UU Nomor 32 Tahun 2009 terkait Perlindungan dan Management Lingkungan, khususnya Pasal 63 (1) (t) yang menyatakan dalam hal perlindungan dan pengelolaan lingkungan hidup, Pemerintah bertugas dan berwenang: menetapkan kebijakan mengenai tata cara pengakuan keberadaan masyarakat hukum adat, kearifan lokal, dan hak masyarakat hukum adat yang terkait dengan perlindungan dan pengelolaan lingkungan hidup. Mencermati bunyi pasal tersebut tegas sekali bahwa pengakuan negara terhadap keberadaaan dan hak-hak masyarakat hukum adat termasuk didalamnya pengetahuan tradisional merupakan sebuah kewajiban dan keharusan.

Namun demikian, meskipun secara teoritis pengakuan negara terhadap keberadaan masyarakat hukum adat di Indonesia dapat dengan jelas kita temukan dalam beberapa peraturan perundangan-undangan nasional, dalam praktik, regulasi-regulasi tersebut dapat dikatakan masih belum mampu secara optimal memberikan perlindungan bagi pengetahuan tradisional di

\footnotetext{
${ }^{23}$ OseiTutu, J. Janewa. “A Sui Generis Regime for Traditional Knowledge: The Cultural Divide in Intellectual Property Law". Marquette Intellectual Property L. Rev., Vol. 15 (2011), Hlm. 164.
} 
Indonesia. Bahkan lebih jauh, rezim hukum paten seringkali dikatakan justru merupakan senjata letigimasi yang ampuh dan turut menyuburkan praktik biopiracy yang dilakukan oleh pihak asing terhadap pengetahuan tradisional suatu negara, khususnya terkait pengetahuan obat-obatan tradisional.

Sebagai contoh, pada tahun 1999 praktik bio-piracy pernah dilakukan oleh sebuah perusahaan kosmetik multinasional Jepang, Shiseido. Perusahaan ini tercatat telah mematenkan 11 tanaman obat tradisional (jamu) Indonesia. Namun karena paten ini mendapat tekanan yang sangat besar dari Pesticide Action Network (PAN) dan organisasi kemasyarakatan lainnya, Shiseido memutuskan untuk membatalkan paten-paten tersebut. ${ }^{24}$

Selain Indonesia, beberapa negara lain pernah mengalami kasus sejenis terhadap sumber daya genetik dan yang berkaitan dengan pengetahuan tradisionalnya. Tahun 1997, hak Paten beras Basmati India oleh the American Company RiceTec Inc; Selain paten atas beras Basmati, tanaman obat tradisional India Neem juga pernah dipatenkan oleh sebuah perusahaan multinasional America W. R. Grace dan US Department of Agriculture (USDA) melalui European Patent Office (EPO). Contoh lainnya paten atas buah Berries Africa (Pentadiplandra Brazzeana) sebagai pemanis rendah kalori oleh seorang warga negara Amerika Serikat. Padahal pengetahuan ini telah diketahui oleh penduduk asli Afrika sejak ratusan tahun lalu. Dan masih banyak lagi contoh penyalahgunaan pengetahuan tradisional yang dilakukan oleh (kebanyakan) negara maju melalui rezim hukum paten.

Kondisi inilah yang pada akhirnya membangkitkan kesadaran sejumlah negara (kebanyakan negara-negara berkembang) untuk menuntut keadilan dan perlakuan yang seimbang atas pemanfaatan pengetahuan tradisional tersebut. Menyadari belum optimalnya peraturan-peraturan yang ada untuk melindungi pengetahuan tradisional di Indonesia, maka pembentukan peraturan baru melalui sui generis law merupakan upaya lain yang harus pemerintah pertimbangkan. Sui generis law sendiri dibutuhkan dalam rangka untuk melindungi hak kekakyaan intelektual yang tidak berwujud (intagible) yang nantinya digunakan untuk melarang siapapun untuk melakukan pemanfaatan terhadap pengetahuan turun temurun ini tanpa sepengetahuan dan ijin dari pemilik pengetahuan.

\section{Urgensi Pembentukan Sui Generis Law di Indonesia}

Penggunaaan ketentuan-ketentuan terkait HKI untuk melindungi pengetahuan tradisional Indonesia terbukti belum mampu efektif

\footnotetext{
${ }^{24}$ Bebeb A.K.N. Djundjunan, Sistem Hukum Internasional Belum Memberikan Perlindungan Efektif terhadap GRTKTCE, dalam Tabloid Diplomasi Komunikasi dan Interaksi, No. 56 Tahun V, July $15^{\text {th }}-$ August $14^{\text {th }}, 2012$, hlm. 8 .
} 
memberikan perlindungan. Tingginya angka 'pencurian' dengan memanfaatkan pengetahuan tradisional terkait sumber daya genetik menunjukkan kebutuhan akan sebuah peraturan yang lebih efektif dalam rangka perlindungan menjadi sebuah keharusan. Beberapa karakteristik dalam sebuah pengetahuan tradisional, perlindungan bagi karya komunal sejarah, dan perlindungan bagi pengetahuan komunal sejarah, mungkin saja pada beberapa hal suitable dengan peraturan tertentu dalam rezim HKI, namun tidak efektif. Karena itu perubahan dan penyelarasan terhadap beberapa pasal HKI juga merupakan sebuah solusi yang dapat diupayakan. Namun demikian, perbedaan sistem dalam HKI dan pengetahuan tradisional menyebabkan amandemen pasal-pasal HKI dirasa tidak akan efisien untuk melindungi pengetahuan tradisional yang secara karakteristik berbeda dengan objek-objek dalam rezim HKI yang lain. Upaya perlindungan sejalan pula dengan peran negara dalam mewujudkan cita hukum Indonesia yang dirumuskan sebagai berikut: ${ }^{25}$

a. negara melindungi segenap bangsa Indonesia dan seluruh tumpah darah Indonesia dengan berdasarkan atas persatuan;

b. negara hendak mewujudkan keadilan sosial bagi seluruh tumpah darah Indonesia dengan berdasarkan atas persatuan;

c. negara yang berkedaulatan rakyat, berdasar kerakyatan dan permusyawaratan perwakilan; dan

d. negara berdasar atas Ketuhanan Yang Maha Esa menurut dasar kemanusiaan yang adil dan beradab.

Dalam rangka pengembangan sui generis law, WIPO melalui The WIPO Intergovernmental Committee on Intellectual Property and Genetic Resources, Traditional Knowledge and Folklore mengajukan beberapa formula yang dapat diadopsi oleh negara-negara anggota dalam rangka untuk melindungi pengetahuan tradisionalnya. Dengan menyesuaikan kondisi dan kepentingan nasional bangsa Indonesia, pemerintah tentu dapat merujuk pada formula tersebut. Sejalan dengan hal tersebut, setidaknya dalam upaya pembentukan peraturan yang besifat sui generis, beberapa unsur-unsur minimum yang harus terkandung dalam sebuah ketentuan sui generis law, diantaranya:

\section{a) Tujuan Pemberian Perlindungan}

Sejalan dengan tujuan HKK, nantinya peraturan sui generis yang akan dikembangkan haruslah juga diarahkan untuk mencapai tujuan dari HKK itu sendiri. Peraturan sui generis ini harus secara tegas memberikan pengakuan terhadap hak-hak dari pemilik pengetahuan tradisional, yaitu mayarakat

\footnotetext{
${ }^{25}$ Yoan Nursari Simanjuntak, Hak Desain Industri (Sebuah Realitas Hukum dan Sosial), (Surabaya: Srikandi, 2005), hlm.214-215.
} 
hukum adat. Singkatnya peraturan sui generis ini harus memiliki tujuan yang berbeda dengan tujuan yang ingin dicapai oleh peraturan yang bersifat 'berwujud' (tangible).

Dalam konteks Indonesia, setidaknya tujuan dari upaya pemberian perlindungan hukum bagi pengetahuan tradisional antara lain; a) untuk menciptakan sistem pelestarian, perlindungan, dan pengembangan pengetahuan tradisional di Indonesia; b) untuk melindungi hak-hak masyarakat adat secara khusus dan atau pemilik pengetahuan tradisional secara luas; c) untuk mengembangkan kapasitas masyarakat pemilik pengetahuan tradisional di Indonesia d) meningkatkan kemampuan inovasi nasional dengan berbasis pada pemanfaatan pengetahuan tradisional; e) untuk menjamin pengembangan sistem akses dan bagi hasil atas keuntungan yang timbul dari pemanfaatan pengetahuan tradisional yang seimbang, dan berkeadilan.

\section{b) Lingkup Perlindungan}

Mengingat bahwa subjek dari pengetahuan tradisional sangat luas, meliputi seni, arsitektur, obat-obatan, dan lain-lain., maka penegasan lingkup dan batasan perlindungan menjadi sangat penting. Secara umum lingkup pengetahuan yang dilindungi meliputi pengetahuan yang; a) dibentuk, dilestarikan, dan disampaikan antar generasi; b) memiliki karakteristik khusus berkaitan dengan masyarakat tradisional yang melestarikan; c) terintegrasi dengan budaya masyarakat tertentu melalui kebiasaan yang berlangsung terus menerus.

Sejalan dengan hal-hal tersebut di atas, rancangan Undang-Undang Pengetahuan Tradisional dan Ekspresi Budaya Tradisional, telah mencoba menformulasikan batasan perlindungan sebagaimana yang dimaksud. Namun demikian, formulasi isi pasal terkait hal ini masih belum dapat dikatakan fix. Hal ini setidaknya terlihat dari masih adanya dua alternatif yang ditawarkan.

\section{Alternatif 1:}

1) Perlindungan pengetahuan tradisional dan ekspresi budaya tradisional mencakup unsur budaya yang:

a) disusun, dikembangkan, dipelihara, dan diturunkan sebagai tradisi; dan

b) memiliki karakteristik khusus sebagai identitas budaya masyarakat tertentu yang melestarikannya;

\section{Alternatif 2:}


1) pengetahuan tradisional yang dilindungi sebagaimana dimaksud pada ayat (1) mencakup ide/gagasan, konsep, keterampilan, pembelajaran dan praktik kebiasaan lainnya, dan inovasi yang membentuk gaya hidup masyarakat tradisional termasuk diantaranya pengetahuan pengobatan termasuk obat terkait dan tata cara penyembuhan, pengetahuan tentang ruang dan waktu, pengetahuan pertanian, pengetahuan lingkungan alam, pengetahuan tentang flora dan fauna, pengetahuan tentang zat dan bahan mentah, pengetahuan tentang anatomi tubuh, pengetahuan tentang astronomi, serta pengetahuan yang terkait dengan sumber daya genetik.

a) kriteria-kriteria dari objek perlindungan.

Apakah semua pengetahuan tradisional dapat dilindungi berdasarkan ketentuan-ketentuan dalam undang-undang khusus nantinya? Untuk menjawab pertanyaan ini, kita dapat merujuk pada negara yang telah menerapkan ketentuan sui generis untuk pengetahuan tradisionalnya. Sebagai contoh Negara Panama. Dalam rangka perlindungan terhadap pengetahuan tradisional, Panama menyaratkan pengetahuan tradisional yang dapat dilindungi hanya pengetahuan tradisional yang memiliki nilai komersil, ${ }^{26}$ mengandung nilai tradisi, ${ }^{27}$ dan pengetahuan tersebut haruslah pengetahuan yang dimiliki oleh satu atau lebih masyarakat adat di Panama. ${ }^{28}$ Selain persyaratan tersebut, kreteria lain yang harus diperhatikan meliputi bahwa pengetahuan tradisional tersebut harus memiliki keaslian, kebaruan, dimiliki oleh individu (individual) atau kolektif (colectivelly).

\section{Keuntungan dari Perlindungan: Pemegang/Pemilik Pengetahuan Tradisional}

Salah satu tujuan perlindungan terhadap pengetahuan tradisional adalah untuk menjamin pelaksanaan pembagian keuntungan bagi pemilik pengetahuan. Namun demikian dalam praktik hal ini tidaklah sesederhana itu. Issue penting yang harus diperhatikan adalah siapa, bagaimana, dan mengapa salah satu pihak dipertimbangkan menjadi pemilik pengetahuan tradisional tersebut berdasarkan peraturan hukum sui generis ini. Dalam kasus tertentu, adakalanya seseorang menciptakan sebuah pengetahuan tradisional, misalnya obat tradisional, tanpa melibatkan atau keterlibatan masyarakat tradisional. Pada kasus lain, pengetahuan tradisional juga seringkali dimiliki oleh beberapa anggota masyarakat dalam suatu kelompok masyarakat. Pengetahuan tersebut diwariskan dan diperoleh di antara individu tertentu dalam sebuah komunitas masyarakat adat. Kemungkinan terakhir adalah bahwa sebuah pengetahuan tradisional diketahui oleh hampir

\footnotetext{
${ }^{26}$ Panama Law No. 20 (June 26, 2000) Article 1.

${ }^{27}$ Panama Law No. 20 (June 26, 2000) Article 15

${ }^{28}$ Panama Executive Decree No.12 (March 20, 2001).
} 
seluruh anggota sebuah kelompok masyarakat (common knowledge), bahkan hingga keluar kelompok masyarakat tersebut. Dalam kasus terakhir, apabila terdapat kesulitan dalam mengidentifikasi siapa pemilik pengetahuan atau karena pengetahuan tersebut diketahui dan atau dimiliki secara bersama dengan berbagai macam kelompok masyarakat adat, maka kedudukan sebagai pemilik pengetahuan digantikan oleh negara. Dengan memahami kondisi-kondisi tersebut, maka sangat diperlukan sebuah ketentuan yang mampu menegaskan dan atau mengidentifikasi siapakah pemilik pengetahuan pengetahuan tradisional.

\section{Jenis Hak yang Diberikan}

Setelah penentuan pemilik pengetahuan tradisional ditetapkan, peraturan sui generis harus mampu pula menegaskan jenis hak yang nantinya akan diberikan, apakah hak ekslusif, hak moral, atau hak remunerasi. Bila berkaca dari banyak negara yang telah menegaskan pengakuan hak masyarakat adat (indigenous people) sebagai pemilik pengetahuan tradisional, umumnya memberikan hak ekslusif kepada pemilik pengetahuan tradisional. Sebagai pemegang hak ekslusif, mereka diberikan hak untuk menahan (withhold) izin pihak ketiga untuk membuat, menggunakan sebuah tawaran penjualan, atau mengimpor berbagai tumbuhan yang mereka kembangkan. ${ }^{29}$

Lebih jauh, merujuk pada konsep hak yang terdapat dalam rezim hak kekayaan intelektual, khususnya hak cipta, hak yang diberikan meliputi economic rights dan moral rights. Dalam kaitannya dengan pengetahuan tradisional, bila didasarkan pada konsep ini, maka economic rights bagi kelompok masyarakat/individu pemilik pengetahuan dapat berwujud kompensasi sejumlah uang yang didapat dari pemanfaatan pengetahuan yang dilakukan oleh pihak ketiga. Sementara moral rights, lebih berupa kewajiban bagi pihak ketiga untuk menerangkan dan mencantumkan sumber pengetahuan pada setiap aplikasi permohonan hak.

\section{Bagaimanakah Hak tersebut Diperoleh?}

Apakah hak tersebut diperoleh secara otomatis tanpa perlu didaftarkan (deklaratif) atau harus melalui pendaftaran (register) terlebih dahulu. Apabila sistem yang dipilih adalah sistem register, peraturan sui generis nantinya harus secara tegas menentukan persyaratan-persyaratan apa saja yang mesti dipenuhi agar dapat memperoleh hak-hak tersebut. Hal ini dilakukan dalam rangka untuk mencegah kesalahan memberikan hak kepada pihak yang tidak berhak. Sebagaimana yang dilakukan oleh negara China,

\footnotetext{
${ }^{29}$ Dutfield, G., Can the TRIPS Agreement Protect Biological and Cultural Diversity? (Biopolicy International No. 19, Nairobi: ACTS Press, 1997). Hlm. 39-40.
} 
pelaksanaan prosedur pemberian hak ini dilakukan dengan mengharmonisasikan ketentuan-ketentuan antara peraturan sui generis dan peraturan-peraturan terkait hak kekayaan intelektual. Sejalan dengan China, meskipun sedikit berbeda, di Thailand pelaksanaan prosedur tata cara pemberian hak dilakukan dengan mengharmonisasikan aturan-aturan dalam peraturan sui generis dengan aturan lain seperti peraturan menteri.

\section{Bagaimanakah Melaksanakan dan Menegakan Hak-Hak Tersebut}

Meskipun memiliki hak, namun hak tersebut akan menjadi sia-sia apabila hak tersebut tidak dapat ditegakkan. Perlindungan terhadap pengetahuan tradisional tidak akan berjalan efektif apabila upaya perlindungan tidak diikuti dengan ketersediaan solusi yang efektif dan cepat terhadap berbagai tindakan penyalahgunaan hak. Tindakan tersebut dapat berupa perintah yang melarang reproduksi dan atau penghentian, dapat pula berupa perintah pemberian kompensasi. Pasal 67 African Model Legislation for the Protection of the Rights of Local Communities, Farmers and Breeders, and for the Regulation of Access to Biological Resources of 2000 adalah salah satu contoh peraturan sui generis yang menyediakan aturan administrasi dan untuk menegakkan hak. ${ }^{30}$

\section{Bagaimana Hak Tersebut Hilang atau Kapan Hak Tersebut Menjadi Kadaluwarsa}

Berkaitan dengan issue ini berkembang dua model. Model pertama yang beranggapan bahwa perlindungan terhadap pengetahuan tradisional harus dibatasi waktu perlindungannya. Perlindungannya dimulai sejak pemanfaatan secara komersil pertama kali dimulai, kemudian diberikan hak untuk mengajukan perpanjangan untuk waktu tertentu. Model kedua beranggapan bahwa perlindungan terhadap pengetahuan tradisional seharusnya tidak perlu dibatasi oleh waktu tertentu. Hak seharusnya tetap

\footnotetext{
${ }^{30}$ Article 67 [2] States that without prejudice to the exercise of civil and penal actions, which may arise from violations of the provisions of this legislation and subsequent regulations, sanctions and penalties to be provided may include: i) written warning; ii) fines; iii) automatic cancellation/revocation of the permission for access; iv) confiscation of collected specimens; v) permanent ban from access to community knowledge and biological resources; [4] The violation committed shall be publicized and reported by the National Competent Authority to the secretariats of relevant international agreements; [4] When the collector conducts his/her operations outside of national jurisdiction, any alleged violations by such a collector may be prosecuted through the cooperation of the government under whose jurisdiction the collector operates. Moreover Art. 68 decisions on agreements regarding access to community knowledge may be appealed through appropriate administrative channels. Recourse to the courts shall be allowed after exhaustion of all administrative remedies.
} 
berlaku sepanjang pengetahuan tersebut masih hidup dan eksis. Dari kedua model tersebut, secara umum model kedua lebih banyak dipakai oleh banyak negara. $^{31}$

\section{Penyelesaian Sengketa}

Salah satu hal penting yang tidak boleh luput dari perhatian adalah, kemungkinan adanya sengketa di masa yang akan datang. Seperti diuraikan di awal, adalah mungkin sebuah pengetahuan dimiliki dan atau diketahui oleh satu pihak tertentu saja. Selain lintas komunitas, lebih luas lintas negara. Kenyataan ini menuntut adanya pengaturan yang jelas dan tegas terkait mekanisme penyelesaian baik pada tingkat nasional maupun regional. Mekanisme penyelesaian sengketa terkait pemanfaatan pengetahuan tradisional dapat dilihat pada Sistem Pakta Andean yang dibentuk oleh kelompok negara-negara latin; Nordic Council of Ministers di antara negara Swedia, Norwegia, dan Finlandia. Selain pembentukan mekanisme penyelesaian sengketa, dimungkinkan pula bagi kedua belah pihak user dan owner pengetahuan tradisional, bila diperjanjikan dapat menggunakan mekanisme arbitrase atau pengadilan.

Selain kesembilan poin-poin tersebut di atas, lebih lanjut, dalam rangka mencapai tujuan dari perlindungan, peraturan sui generis ke depannya harus pula mempertimbangkan beberapa hal berikut: ${ }^{32}$

a. untuk mencegah disintegrasi bangsa, perlu diperhatikan bahwa Indonesia merupakan negara yang terdiri dari beratus-ratus suku, dan beragam budaya. Masing-masing memiliki kebudayaan yang berbeda-beda, termasuk pengetahuan tradisional terhadap pemanfaatan tanamantanaman obat. Fakta ini kemudian menimbulkan kemungkinan apabila satu pengetahuan tradisional diketahui bahkan dimiliki oleh lebih dari satu masyarakat adat. Sebagai contoh; pengetahuan masyarakat Jawa terhadap minuman yang berfungsi obat, yaitu Jamu. Dengan minum Jamu, masyarakat Jawa percaya bahwa stamina tubuh akan terjaga dan akan prima. Namun pengetahuan akan khasiat jamu ini tidak hanya diketahui oleh masyarakat Jawa saja. Pengetahuan khasiat jamu sebagai minuman yang berfungsi obat, merupakan pengetahun yang yang diketahui oleh hampir seluruh masyarakat Indonesia. Bahkan, masyarakat luar Jawa pun banyak yang mengkonsumsi jamu dalam kehidupan seharihari.; ${ }^{33}$

\footnotetext{
${ }^{31}$ Dokumen WIPO/GRTKF/IC/5/8 (April 28 $8^{\text {th }}, 2003$ ).

${ }^{32}$ Sardjono, Agus, Hak Kekayaan Intelektual dan Pengetahuan Tradisional). (Bandung: Alumni, 2010), hlm. 251.

${ }^{33}$ Ibid, Hlm. 252-253.
} 
b. peraturan sui generis harus mampu memperkuat kontrol negara terhadap kekayaan alamnya, sebagaimana yang diamanatkan dalam konstitusi negara kesatuan Republik Indonesia yaitu UUD 1945 Pasal 33;

c. peraturan sui generis nantinya haruslah memberikan pengakuan yang tegas terhadap hak-hak masyarakat adat sebagai pemilik pengetahuan tradisional sekaligus sebagai penyedia dari sumber daya genetik;

d. mekanisme untuk kompensasi moneter dan non-moneter bagi masyarakat adat terhadap pemanfaatan pengetahuan tradisional mereka;

e. pengakuan secara tegas untuk pengetahuan tradisional sebagai prior art; dan

f. Peraturan sui generis haruslah mampu memastikan pengembangan kreatifitas yang berkelanjutan bagi masyarakat adat. Dengan demikian seluruh masyarakat Indonesia nantinya dapat melakukan pemanfaatan dan pengembangan obat-obatan tradisional. Dengan kata lain, hukum diciptakan tidak boleh menghambat perkembangan kreativitas dari pengetahuan tradisional itu sendiri.

\section{Penutup}

Kesimpulannya, bahwa perlindungan terhadap pengetahuan tradisional tidak dapat dilakukan hanya dengan mengandalkan penggunaan rezim hukum kekayaan intelektual. Meskipun harus diakui, rezim tertentu dalam hukum hak kekayaan intelektual seperti rezim hukum paten, rezim hak cipta, ataupun indikasi geografis pada beberapa aspek dapat digunakan untuk melindungi pengetahuan tradisional. Namun demikian, penggunaan rezim hukum hak kekayaan intelektual properti dianggap tidak dapat memberikan pencapaian tujuan kesetaraan dan keseimbangan bagi masyarakat hukum adat. Kekurangan dari rezim hukum kekayaan intelektual, nantinya diharapkan dapat dilengkapi oleh peraturan sui generis. Dalam rangka pengembangan peraturan sui generis tersebut, dengan merujuk pada usulan dari The WIPO Intergovernmental Committee on Intellectual Property and Genetic Resources, Traditional Knowledge and Folklore, setidaknya terdapat beberapa unsur-unsur minimum yang harus terkandung dalam sebuah ketentuan sui generis, meliputi tujuan pemberian perlindungan; lingkup perlindungan; kriteria-kriteria dari objek perlindungan; keuntungan dari perlindungan: pemegang/pemilik pengetahuan tradisional; jenis hak yang diberikan; bagaimana hak tersebut diperoleh; bagaimana melaksanakan dan menegakan hak-hak tersebut; bagaimana hak tersebut hilang atau kapan hak tersebut menjadi kadaluwarsa; dan penyelesaian sengketa. 


\section{Daftar Pustaka}

\section{A. Buku, Jurnal, dan Dokumen-dokumen}

African Technology Policy Studies Network, Special Paper Series No. 44, 2012.

Dutfield, G., 1997. Can the TRIPS Agreement Protect Biological and Cultural Diversity?, dalam Biopolicy International No. 19, ACTS Press, Nairobi.

Dokumen WIPO/GRTKF/IC/3/9 (May 20 ${ }^{\text {th }}, 2002$ ).

Dokumen WIPO/GRTKF/IC/5/6 (May 14 ${ }^{\text {th }}, 2003$ ).

Dokumen WIPO/GRTKF/IC/5/8 (April 28 ${ }^{\text {th }}, 2003$ ).

Dokumen WIPO/GRTKF/IC/6/8 (December $\left.15^{\text {th }}, 2003\right)$.

Draft RUU perlindungan dan pemanfaatan Kekayaan Intelektual Pengetahuan Tradisional dan Ekspresi Budaya Tradisional.

Hasan, Emmanuel, et.al., 2010. Intellectual Property and Developing Countries: a review of the Literature. RAND Corporation: UK.

Jurnal Supremasi Hukum, Volume III No. 1 Tahun 2010, FH Univ. Jakarta: Sahid Jakarta

Karin Timmermans (ed), "TRIPS, CBD and Traditional Medicine: Concept and Questions", Report of an ASEAN Workshop the TRIPS Agreement and Traditional Medicine Jakarta, 13-15 Feb 2001.

Konvensi Keanekaragaman Hayati

Moni Wekesa, 2006. What is Sui Generis System of Intelektual Property Protection?, dalam African Tecnolgy Policy Studies Network (ATPS): Kenya: Nairobi.

Muhammad Djumhana, R. Djubaedillah, 2014. Hak Milik Intelektual Sejarah, teori, dan Praktiknya di Indonesia, (Bandung: PT. Citra Aditya.

Panama Law No. 20

Panama Executive Decree No. 12

Rabodo Andriantsiferana, 2003, Traditional Knowledge: What is it and How (if at All) is it to be Protected? Traditional Knowledge Protection in the African Region, Conference on Biodiversity, Biotechnology and the Protection of Traditional Knowledge, Saint Louis: USA, April $4^{\text {th }}$ $6^{\text {th }}$..

Sardjono, Agus, 2010, Hak Kekayaan Intelektual dan Pengetahuan Tradisional, Bandung: Alumni.

Simanjuntak, Yoan Nursari, 2005. Hak Desain Industri (Sebuah Realitas Hukum dan Sosial), Surabaya: Srikandi.

Tabloid Diplomasi Komunikasi dan Interaksi, 2012, "Sistem Hukum Internasional Belum Memberikan Perlindungan Efektif terhadap GRTKTCE, No. 56 Tahun V, July $15^{\text {th }}-$ August $14^{\text {th }}$. 
WIPO Publication No. 920 Booklet No. 2.

\section{B. Sumber Elektronik}

Avilia, Dewi, "Traditional Knowledge Database: A Defensive Measure Against Traditional Knowledge Cross Border Misappropriation, Master Thesis (Tilburg University, Netherland), http://arno.uvt.nl/show.cgi?fid=115001

Correa, Carlos M, "Protection and Promotion of Traditional Medicine Implications for Public Health in Developing Countries", http://apps.who.int/medicine docs/pdf/s4917e/s4917e.pdf

Grabet, Christoph Beat \& Martin A. Girsberger, "Traditional Knowledge at the International Level: Current Approaches and Proposal for a Bigger Picture That Includes Cultural Diversity" http://www.unilu.ch/files/graber-girsberger_tkcd_endg.pdf

Native Science Organization, "What is Traditional Knowledge: Traditional Knowledge Systems in the Arctic", http://www.nativescience.org/html/traditional_knowledge.html

OseiTutu, J. Janewa. "A Sui Generis Regime for Traditional Knowledge: The Cultural Divide in Intellectual Property Law”, dalam Marquette Intellectual Property L. Rev., Vol. 15 (2011), http://scholarship.law.marquette.edu/iplr/vol15/iss1/3/

Secretariat of $\mathrm{CBD}_{2}$ Traditional Knowledge and the Convention on Biological Diversity (CBD), http://www.cbd.int/traditional/intro.shtml 